\title{
Evolution and Emergence
}

Comparing C. Lloyd Morgan's Emergentism and G.H. Mead's Processual Ontology

\section{Guido Baggio}

\section{(2) OpenEdition \\ 1 Journals}

\section{Electronic version}

URL: http://journals.openedition.org/ejpap/1680

DOI: $10.4000 /$ ejpap. 1680

ISSN: 2036-4091

\section{Publisher}

Associazione Pragma

\section{Electronic reference}

Guido Baggio, «Evolution and Emergence », European Journal of Pragmatism and American Philosophy [Online], XI-2 | 2019, Online since 24 December 2019, connection on 15 June 2020. URL : http:// journals.openedition.org/ejpap/1680 ; DOI : https://doi.org/10.4000/ejpap.1680

This text was automatically generated on 15 June 2020 .

\section{(c) (i) (9)}

Author retains copyright and grants the European Journal of Pragmatism and American Philosophy right of first publication with the work simultaneously licensed under a Creative Commons AttributionNonCommercial-NoDerivatives 4.0 International License. 


\title{
Evolution and Emergence
}

\author{
Comparing C. Lloyd Morgan's Emergentism and G.H. Mead's Processual \\ Ontology
}

Guido Baggio

\section{AUTHOR'S NOTE}

For helpful comments on an earlier version of this paper I am grateful to two anonymous referees of the Journal.

\section{Introduction}

1 In the winter of 1895-1896, the British zoologist and comparative psychologist C. Lloyd Morgan delivered some lectures in Boston, New York and Chicago. While in Boston delivering the Lowell Lectures, published the very same year with the title Habit and Instinct (Morgan 1896), he stayed for a week in the house of William James, to whose theory of emotion he dedicated part of his lectures. In the preface of the volume he also mentions the evolutionary biologist Charles $\mathrm{O}$. Whitman, at the time head professor of the new-born Department of Biology at the University of Chicago, with whom Morgan spent some time during his stay, working on experiments on instinct theory with pigeons. ${ }^{1}$

2 We can suppose that when Morgan was in Chicago he also met George Herbert Mead. ${ }^{2}$ Mead arrived at the University of Chicago in 1894, at the time when he was trying to explain emotion and the organic evolution of habit, attention and mind within an experimentalist physiological perspective. In particular, Mead was focusing on physiological psychology and psychophysics as well as on comparative psychology, of which Morgan, as disciple of George J. Romanes, was one of the main proponents. It is therefore highly possible that Mead attended Morgan's lecture on "Instinct and Habit" at the University of Chicago, and we can also conjecture that they had the chance to discuss their common interests: they were both deeply concerned with physiological 
psychology and the evolutionary processes in behaviour. In support of our conjecture is the fact that Mead wrote a critical review of Morgan's An Introduction to Comparative Psychology, published the following year (Mead 1895b). What is even more interesting, however, is the fact that early in the twentieth century both Morgan and Mead elaborated their own theories of emergence and emergent evolution in which their respective research interests found a philosophical synthesis. The Gifford Lectures, published with the title of Emergent Evolution (Morgan 1927) are in fact Morgan's philosophical explanation of the evolution process and his philosophical testament, whereas the Carus Lectures, published posthumously with the title The Philosophy of the Present (1932) represent Mead's last attempt to elaborate a theory of emergence through which to interpret the theory of the evolution of mind and language he had developed over the years.

In what follows we will try to detect the most significant turning points on the parallel intellectual paths that led Lloyd Morgan and Mead to develop independently their theories of emergence, taking as a starting point the lectures given by Morgan in the United States. Both theories of emergence are in conditioned the reflections that the two thinkers had developed over the years and which have their roots in the early 1890s.

4 The article will be developed as follows. I briefly describe Morgan's conception of organic and mental evolution as elaborated in the 1890s and summarised in his Lowell Lectures. I introduce, then, Mead's early writings on psychophysics and comparative psychology, pointing out a similarity between Mead and Morgan's ideas on organic and mental evolution at that time. Then I examine their theories of emergence from the 1920 s, pointing out more interesting similarities and dissimilarities.

5 The aim of the article is to make a contribution to the contemporary debate on emergence by focusing on two authors that first elaborated a theory that tried to synthesize the biological, the psycho-physiological and the social dimensions of emergent processes. The debate about the concept of "emergence" is in fact particularly varied (see Kim 1999, 2005, 2006a,b; Cunningham 2001; Pihlström 2002; ElHani 2002; El-Hani \& Pihlström 2002; Chalmers 2006; Bedau \& Humphreys 2008; Okasha 2012; Humphreys 2016; Sartenaer 2016; Lota 2017; Tononi \& Koch 2015; Hodgson 2000; Sawyer 2001; Lawson 2013). ${ }^{3}$ Shedding light on the conceptions of two of the main figures in the history of the theories of emergence would contribute to a more richlyarticulated and complete historical-theoretical understanding of a debate which is being currently renewed.

\section{Lloyd Morgan between Ontological Monism and Epistemological Dualism}

Morgan presented the Lowell Lectures at Boston, New York and Chicago, and published them with the title Habit and Instinct (Morgan 1896). He was at that time deeply committed to evolution theory and James' functionalism. ${ }^{4}$ More specifically, he was studying the relationship between the hereditary aspects related to the genes ${ }^{5}$ and the role behaviour plays in the variation of those aspects, developing his observation of behavioural traits of different types of animals that prefigured those in more complex organisms. It is from these observations and interests that he wrote An Introduction to Comparative Psychology (1903 [1894a]), which soon became the manifesto of the modern 
comparative psychology and behaviourist movement. An Introduction represented in fact a shift away of Morgan's attitude towards comparative psychology from a first critical acceptance of Romanes' approach based on a systematization of the available anecdotal evidence towards a thorough-going experimental approach (Costall 1998; Boakes 1984). We find here formulated what was later known as "Morgan's canon," which became a central and founding principle that has profoundly determined the history of comparative psychology, illustrating the overcoming of the pre-scientific and anthropomorphic dimensions of zoopsychology as it had been presented by George John Romanes. ${ }^{6}$

7 Following this new approach, in his Lowell Lectures Morgan presented some of the results of his studies and observations on animal behaviour and described the relation of organic and mental evolution as based on the interaction between congenital instincts and inherited habits, from an evolutionary perspective. His main thesis was that organic evolution occurred in the working together of plastic modification and germinal variation, and therefore habits and instincts were the expression of respectively individual modification and congenital variations of germinal origin. At the basis of this thesis was the hypothesis that ontogenetic evolution of complex neural states begins with simpler energy states in the germ-plasm, concluding that advanced states of consciousness evolved from infra-conscious states corresponding to energy transformations in the germ-plasm (Morgan 1903: 329), and that infra-consciousness, which always accompanies brain action, is associated with all forms of energy. ${ }^{7}$

8 Building upon this hypothesis, in Habit and Instinct he contended that instinctive activities are characterized by a certain amount of definiteness which is hereditary and "not acquired in the course of individual experience." Whereas, habits are the result of individual acquisition, and are "stereotyped by repetition in the course of the experience of the organism" (Morgan 1896: 16-7). Modifications as such, therefore, are not inherited but are the condition under which "congenital variations are favoured and given time to get a hold on the organism, and are thus enabled by degrees to reach the fully adaptive level" (ibid.: 321). ${ }^{8}$

9 In this frame, where does consciousness fit? Morgan, who in An Introduction referred to William James (borrowing from his conception of consciousness), argued that the emergence of consciousness is part of the first instinctive response of an individual organism to a sensible stimulus which provides the initial experience by which subsequent conscious guidance of behaviour is controlled. The co-ordination involved on the occasion of the first performance is automatic, or instinctive, and cannot be regarded as under the guidance of consciousness. However, the carrying out of the activity furnishes data to consciousness in the light of which "the subsequent performance of a like activity may be perfected, or modified, or checked." (Morgan 1896: 6). The "initial bit of conscious experience" (ibid.: 135) therefore emerges with the primary experience-data, already grouped according to the nature of the organic response, and it is related to a "blind" impulse, that is, an internal state which prompt us to perform certain actions (ibid.: 138).

10 However, Morgan was ambiguous on what an "impulse" is, defining it as a "state of consciousness" regarded as the result of physiological conditions with certain organic accompaniments. The ambiguity is related to the fact that, on the one hand, Morgan identified impulse with a state of consciousness; on the other hand, he specified that the presence of a conscious impulse in the case of an instinctive activity is hypothetical 
but that one may legitimately infer from observed facts that "the organism under the influence of a stimulus or complex group of stimuli is thrown into a state of unstable equilibrium, and that stability is reached through the appropriate response" (ibid.: 140). It seems, in other words, that on the ontological level he assumed the core thesis of the functionalist psychology, according to which psychic phenomena are not separate elements, but maintaining it together with an epistemological more classic parallelist perspective on consciousness. ${ }^{9}$ This idea followed from Morgan's epistemological view as deeply rooted in an evolving ontological monism which he was developing during those years. ${ }^{10}$ His rejection of Cartesian ontological dualism in favour of a monism, according to which brain and mind are the same stuff, ${ }^{11}$ went together with his epistemological dualism, according to which mind and matter were both "constructs," or outcomes of different analyses of experience: that of the psychologists - the conscious experience, that is the "metakinetic" manifestations -, and of the physiologists - the "kinetic" manifestations. ${ }^{12}$ In other words, Morgan was seeking to join together an epistemological associationist perspective with an ontological monism. However, despite his conviction that physiological common descent was something like an a priori truth, Morgan could not dismiss so easily the problem raised by the qualitative gaps between organisms.

\section{Mead on Energy and Comparative Psychology. Some Early Sporadic Connections to Lloyd Morgan's Works}

11 As mentioned in the introduction, Mead had known about Morgan's works since the 1890s. He was critically interested in Morgan's ideas and it would make sense that he attended his lecture on "Instinct and Habit" at Chicago in 1895. Mead was at the time increasingly involved with an experimentalist physiological perspective through which he wanted to explain emotion and the organic evolution of habit, attention and mind. In a letter to the Deweys of 1895 , Mead reported some results of a research study on stimulus and adaptation, arguing that he discovered the synthetic principle at the basis of the development stated in biology, namely "that every advance is the response of the organism to new or enlarged food supply i.e. a response to a stimulus not to an influence " and that "adaptation of the sensomotor system, at anyone prior - distinguished from the alimentary system can then take place only within the comparatively narrow limits set by advance made in the alimentary system in response to the new stimulus." ${ }^{13} \mathrm{He}$ then concluded that his discovery would have allowed him to "harmonize Darwin Weissmann Loeb," that is, to harmonize Darwin's idea that natural selection needs variation and the heredity of at least a part of it, with Weissmann's theory of hereditariness of germline cells independently from somatic cells and Loeb's theory that environmental factors affect growth, development, and behaviour. ${ }^{14}$ In other words, Mead was convinced that he had discovered the synthetic principle of variation, selection, and hereditariness, on which, as we have seen, Morgan was also working at that time. ${ }^{15}$

In his 1895 review of An Introduction to Comparative Psychology, Mead welcomed Morgan's work as an attempted overcoming of the homocentric character of psychical analysis, which has distorted comparative psychology. He also noted that the monism postulated by Morgan was not really in contrast with his dualistic standpoint on the physical and psychical aspects, which could be regarded, according to Morgan's analysis, 
indifferently as two aspects of the same curve or as simply running parallel with each other. Mead identified that Morgan's thought, in fact, was dominated by analogies between the two aspects. However, as he specified, such analogies were just "makeshift": an expedient carrying with them much error for being incompletely analysed and abstracted. He then highlighted the limit of the conceptual apparatus of comparative psychology since the treatment of the physical and the psychic was addressed, with little success, in terms of analogy, without any attention to the purely logical distinction between the physical and the psychic. He thus denounced the lack of an in-depth analysis of the fundamental concepts, since the analogies were, to his eyes, rather gimmicks than the explanations themselves and had the value of illustration rather than true knowledge (Mead 1895b: 401). ${ }^{16} \mathrm{He}$ was of the opinion that comparative psychology needed "a thoroughgoing analysis of its fundamental concepts to put it upon its feet," by freeing its tools, "i.e., in the definite formulation of a psychological method as ultimately distinct from those of the physical and biological sciences" (Mead 1895b: 400).

In the following years, he developed his research with at the basis the idea that the ontogenetic study of the mental phenomenon in human beings is closely intertwined with the phylogenetic study of human consciousness in distinction from inferior forms of life. Although Mead criticised the epistemological limits of Morgan's comparative psychology, from a methodological perspective which was similar to Morgan's, Mead found in the observation of behaviour an indispensable method for the study of the psychic processes of the subject involved in the interactions with physical and social environment. "Behaviour" became the key notion since it allowed to interpret psychophysical processes in a broader social perspective through which to analyse the social act in which psychic phenomena were expressed..$^{17}$ It has to be noted, however, that even if the method of the observation of behaviour became a key element of Mead's social-behavioural approach to language and mind, he did not accept John B. Watson's reductionist approach. ${ }^{18}$ On the contrary, he believed that it was not possible to explain psychic phenomena by just referring to external behaviour, and regarded "mental behaviour" as just as functionally essential as non-mental behaviour to human conduct, but partially explainable through the latter.

Mead's investigations finally resulted in a bio-social perspective of the organic continuity of the physical and the psychical, according to which the emergence of minds and selves are rooted on the:

innate or hereditary [...] physiological mechanism of the human central nervous system, by means of which the genesis of minds and selves out of the human social process of experience and behavior - out of the human matrix of social relations and interactions-is made biologically possible in human individuals. (Mead 2015: 237n)

This perspective was in line with the idea Morgan expressed in Emergent Evolution, according to which in any organism there is something physiologically given that "affords only a physical basis on which there is founded the conscious reference that supervenes" (see Morgan 1927: 107). Like Morgan, Mead also finally came to interweave psychological reflections into a broader philosophical fabric in order to highlight the close interdependence between the emerging nature of the psychic sphere with respect to physical phenomena and the emerging nature of the knowledge process of the surrounding reality. 
16 To better understand the precise connections between Mead and Morgan, let's now move on to their theories of emergence.

\section{Evolution and Emergence: Morgan's Emergentism and Mead's Processual Ontology}

17 The Gifford Lectures, delivered in 1922, are Morgan's philosophical explanation of the evolution process which became a milestone of first-generation organicists. As already mentioned, his idea, elaborated in 1890s, that advanced states of consciousness emerged from infra-conscious states corresponding to energy transformations in the germ-plasm, and that infra-consciousness was associated with all forms of energy accompanying brain action, forced Morgan to adopt a more fundamental monistic view which, however, "brought him precipitously close to the brink of panpsychism," though eventually "did not hurtle him headlong into that doctrine" (see Richards 1977: 19-20). Thus, he thought the idea of an emergent evolution could be a solution to the epistemological gap. He first used the term "emergence" in 1913 (Morgan 1913: 29-33), referring to J. S. Mill's and G. H. Lewes' concepts of emergence. ${ }^{19}$ Hereafter Emergence became a foundational premise to address from a philosophical perspective the qualitative gaps between organisms and the evolutionary incongruities..$^{20}$ In particular, Morgan (1927) recognized the core role of the notion of emergence and he tried to overcome epistemological associationism by moving towards an evolutionary epistemology that seemed more in line with the assumptions of an ontological monism, showing his constructive dialogue with a number of contemporary figures who were engaged more or less explicitly with the question of the "advent of novelty" (Morgan 1927: 2), from Samuel Alexander to Henri Bergson, Alfred North Whitehead, and Bertrand Russell.

Some years later, in December 1930, Mead delivered the Paul Carus Lectures, in which he sketched out a processual ontology that presented a bio-social account of emergence similar to Morgan's. Similarly to Morgan's Emergent Evolution, one of the dominant strains of Mead's Philosophy of the Present is the philosophy of nature considered as the characteristic contribution of the Anglo-American philosophy of the 1920s, pioneered by Alexander's Space, Time, and Deity (1920). ${ }^{21}$ However, differently from Morgan, Mead engaged more with his interpretations of Bergson's vitalism and Whitehead's hypothesis of the organization of perspectives in nature (Whitehead 1919; 1920; 1925), as well as with an interpretation of the theory of relativity considered from a social point of view..$^{22} \mathrm{He}$ attempted to develop a synthesis with respect to the possible integration of his social-behavioural psychology with the theory of relativity, and to avoid a psycho-physical dualism and a reductionist naturalism. It is therefore comprehensible that he used a terminology that was more familiar to him.

\section{Relatedness and Sociality}

In his lectures, Morgan proposed a doctrine of emergence that he considered "the very antithesis" to any mechanistic interpretation of life and mind (Morgan 1927: 8). In particular, he contended that in evolution all emergent events proceed on the hypothesis that "there is a natural, coherent, and consistent plan of relatedness to which its interpretation has reference." Therefore, the "emphasis on orderly 
relatedness as a feature of reality worthy of such emphasis forms a plank in the platform of emergent evolution" whose reality has "relatedness, fundamentally orderly" as a cardinal feature (ibid.: 181-3). Accordingly, emergence is some "new kind of relation" (ibid.: 64), namely, a new entity that appears at each ascending step. As Morgan argues:

That which becomes the stuff at the higher level of emergence is never quite what it was at the lower level from which it was derived - otherwise one would have resultants only and not emergence. Under emergent evolution there is progressive development of stuff which becomes new stuff in virtue of the higher status to which it has been raised under some supervenient kind of substantial gotogetherness. (Ibid.: 192-3)

Morgan refers to the supervenience of new kinds of relatedness on the basis of which the ways in which the lower-level events are involved run their course differently in virtue of the presence of the supervenient event. So that, when life is supervenient, the physical events involved run their course differently in virtue of its presence. He then distinguishes between intrinsic and extrinsic relatedness, the first being that "which obtains wholly within any given system," whereas the extrinsic relatedness is that of a system to some other systems (ibid.: 19). In more general terms, any entity as such is an instance of relatedness. A person, an organism, an atom, are instances of relatedness in any concrete situation in which they play their part, each in respect to others. And "it is as an integral whole of relatedness that any individual entity, or any concrete situation, is a bit of reality" (ibid.: 69).

Within this framework, the passage from inorganic to organic life, and to mind, is part of an emergent evolution in due historical order. Morgan gives a diagrammatic expression of emergent evolution as a pyramid (Figure 2) that responds to a double constraint: "(i) that imposed by the constitutive structure of nature; and (ii) that imposed by the regulative structure of a logical field as such" (ibid.: 179). So that each higher entity in the ascending series is an emergent "complex" of many entities of lower grades, within which a new kind of relatedness provides integral unity.

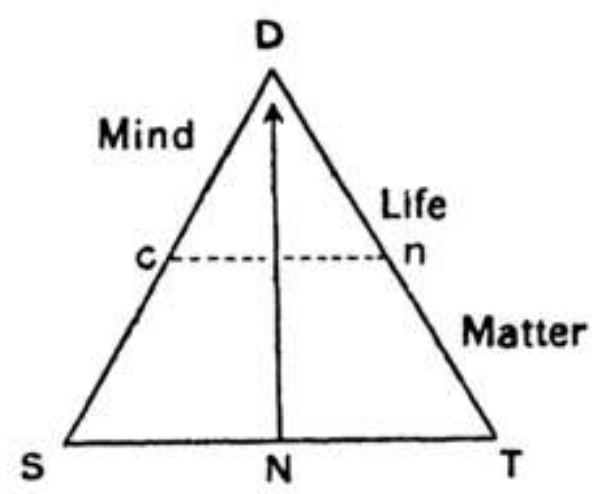

Figure 1

Life and mind are unified with the material and emerge through natural departures in the evolutionary passage of physicochemical events. Emergent evolution is "merely the recognition that new phases of the same underlying stuff have radically different, unpredictable characteristics, and that these traits have come about seemingly de novo over the course of time" (Peterson 2016: 74). So that which is recognized as conscious 
life, sentience, even logic, evolves as reconfigurations in the way the underlying mindstuff relates to itself:

When two or more kinds of events, [...] as A, B, and C, co-exist on one complex system in such wise that the $C$ kind involves the co-existence of $B$, and $B$ in like manner involves $A$, whereas the A-kind does not involve the co-existence of $B$, nor $B$ that of $C$, we may speak of C, as, in this sense, higher than B, and B than A. Thus, for emergent evolution, conscious events at level $C$ (mind) involve specific physiological events at level B (life), and these involve specific physico-chemical events at level A (matter). No C without B, and no B without A. No mind without life; and no life without "a physical basis." (Morgan 1927: 15)

New stages of emergence are not discontinuous to the previous one, so that reflective consciousness involves as its natural basis a lower plane of consciousness, which is at the infra-conscious level. This level is unreflective and perceptual, and in like manner involves a basis of life on which it is founded; and this again involves a physicochemical basis on which it, in turn, is founded. So that in proceeding downwards in the pyramid of emerging evolution, the ultimate basis is a world of purely physical events (and their correlates) in the changing spatial and temporal relationship. But the way in which natural events take place at each level depends "on the kind of relatedness supervenient at that level" (ibid.: 60). In other words, there are different epistemological levels from which to regard entities in relation. In the universe as a natural system all relatedness is intrinsic; on the other hand, for an electron as a physical unit, all relatedness is extrinsic. Within any given instance of relatedness the terms and their relation are homogeneous. That is to say that relation is continuous and the events are fluent in nature. The same is true with the time-interval between two moments: it is "just the temporal relation that it is" (ibid.: 75). Space-time is intrinsic and extrinsic to physical events but not a priori to them. The fluency of events is in that which is methodologically conceived as a space-time frame. In this frame, no relation is divisible. But it is possible that under some method of conventional treatment, say that of mathematics, an indivisible spatial or temporal distance may be co-related with a "stretch," that is with an extension (a kind of specious present), which is divisible and may comprise as many terms as we choose to make therein.

Under internal relations things in some ways change in their intrinsic nature under causal influence. For instance, when moon and earth are set in a joint field of gravitative relatedness, each is intrinsically changed through the differential strain that results, with tidal deformation of some measure. The external relations, on the other hand, do not make any difference to the things as things. For instance, whether a book be on the shelf or on the table makes no difference whatever to the book as a thing, which is what it is in this respect. However, regarded as a place-term in homogeneous relatedness with another such term, its position between two others on the shelf is quite different from that which it holds when it lies on my desk. In this sense, its "positional status is of the so-called internal order; and its character, as spatial term in this respect (not, of course, as thing), is thus determined" (ibid.: 78).

Now, Mead's idea, in fact very similar to Morgan's, was that of a connection, of a "relatedness," among factors that are part of an evolutionary process which allows the possibility of new events to emerge. In his theory of emergence he uses the term "social" with a similar meaning as Morgan uses the term "relational." ${ }^{23}$ According to Mead, in fact, the world is a complex of emerging events that develops diachronically, and it is important to pay attention to what preceded what is taking place so that "the 
direction of temporal progress may determine what the world is going to be" (Mead 2002: 45). In this frame, in which the emerging/continuous dialectic is played out, the evolutionary process allows the possibility of qualitatively new events, which when they happen appear discontinuous, but which the process of adaptation links to the continuous process of evolution through a reconstruction that involves both the event and its structural context. Every new element diverts the direction of the future and evolutionary history towards unpredictable paths and at the same time determines a reinterpretation of the past - seen as the set of determining conditions in the light of the new element that has emerged.

Mead referred to the principle of sociality as an explanatory principle of the dynamic interaction between the acting perspectives, trying to give an experiential reading of the temporality of thought. In fact, he argued that the process of the emergent phenomenon is displayed in a diachronic extension of the present in which the dimensions of past and future are included in the light of emerging novelty, and as a function of the conditioned and the conditioning. In particular, at the opening of his Carus Lectures, Mead claimed that "reality exists in a present" (ibid.: 35), the latter being "a certain temporal process going on in experience" (ibid.: 45). Referring to Bergson's notion of "duration" (Bergson 1910), he notes that the present always implies the interweaving of the different elements of a state, not only in the sense that what is taking place extends to what comes next, but also in a rather more "pragmatic" sense, according to which such interweaving is at the root of meaning and value in things (Mead 1936: 297). The present is, therefore, a temporal diffusion of events extended enough to make it possible for the event to be what it is; or, as Whitehead (1925: 104) would have said, the event realizes itself as a totality "within the specious presents." One event is distinguished from another for its being a becoming which affects the inner nature of that event..$^{24} \mathrm{~A}$ present, in contrast with the abstraction of mere passage, is not a fragment cut outside the temporal dimension of the uniform becoming of reality. Its primary reference is "to the emerging event, i.e., the occurrence of something which is more than the processes that have led up to it and which by its change, continuance, or disappearance, adds to later passages a content that they would not otherwise have possessed" (Mead 2002: 52). The social nature of the present arises out of its emergence. Identifying sociality with this result is merely identifying it with the system. If emergence is a characteristic of reality, this phase of adjustment, which takes place between the ordered universe before the emergent arose and the universe after it coming to terms with the newcomer, must also be a characteristic of reality. Mead refers to "the phase betwixt and between the old and the new system" (ibid.: 73). The social is, then, "the capacity of being several things at once" (ibid.: 75). In Mead's view, the essential nature of the present is therefore emergent in its becoming and disappearance, and in the process of readjustment that the emergent implies. As Bella argues, the events that emerge thus reveal "a social form precisely in the perceived actuality of their emergence and directed with respect to the present." In this form, the past is "the conditioning that, preserving previous systemic relations, emerges in the present from the way in which the relationship between events develops and, in part, the condition for the development of the reality that is immediately imminent" (Bella 2016: 66).

27 Similarly to Morgan, Mead contended that any variation that occurs in the world is a qualitative novelty that finds the conditions of its emergence in the relational context in which it originates, and in turn reconstructs the same context starting from an 
evolutionary novelty which cannot be reduced to its conditions. However, it is important to note that differently to Morgan, Mead does not admit a teleological perspective. According to Morgan, in fact, emergent evolution is the expression of an orderly and progressive development of nature in which the new emerging character, namely some new kind of relatedness among pre-existing events, is unpredictable before its appearing, for "ex hypothesis, there are no such events as yet in existence" (Morgan 1927: 6). However, Morgan specified, "if there be a natural plan of emergence, then every effect is strictly determinate in accordance with the nature of that plan." Novelty itself shall be mentioned under the rubric of causation, being "caught up in the web of causal nexus under suitable acknowledgment." This means that unpredictability is not due to the nature of novelty, rather to "our partial knowledge of the plan of emergence up to date, and our necessary ignorance of what the further development of that plan will be" (ibid.: 282). There is, in other words, a "natural plan" that we cannot know a priori, but that is part of the causal nexus explicable by a causal explanation, once that novelty has emerged. To Morgan's idea of relatedness is thus linked the relation between logical sense and natural direction. There is a sense of the relation which is characteristic also of the logical relation. Where we are dealing with some passage of events, in objective regard, the logical sense is accordant with the direction of passage. There is, in other words, a diachronic connection which has an evolutionary origin. However, even where there is an onward flow of events in the space-time frame that we construct for their interpretation, we may think of them either as downstream or upstream, forwards or backwards.

Differently from Morgan, Mead considers the single act to be teleological, not the natural order. The conditions of the emergence, while necessary, do not determine in its full reality that which emerges, but are present in it. Thus, although the emerging event is conditioned by the past, it cannot be deduced from it, nor can it be causally reduced to it. And since the present is not entirely determined by past conditions, the past did not contain the present when it appeared. The past is in continuity with the present only a posteriori, through a reconstruction that selects the conditions for the explanation and justification of the emergent. Between emergent event and the conditions under which it occurs, there is a causal relation which sets up a history relative to that event that can be seen as a historical emergence. ${ }^{25}$ This means that the emergent event is not caught up in the web of a causal nexus, exactly because there is not, according to Mead, a "natural plan of emergence" (so that every effect is strictly determinate in accordance with the nature of the plan), and the emergent event is not new only because of our "necessary ignorance of what the further development of that plan will be" (Morgan 1927: 282). What the environment or social structure represents is a "statement of the world out of which the emergent has arisen, and consequently the conditions under which the emergent must exist, even though this emergence has made a different world through its appearance" (Mead 2002: 69). The world has become a different world because of the event, and the "new" world, that is the new system of relations, retroacts changing the previous laws.

\section{Minded Behaviour}

Another similitude between Morgan's and Mead's theories of emergence is the centrality attributed to behaviour and perception in the explanation of the emergence of the mind and selves. 
Morgan's phylogenetic explanation of the emergence of consciousness is in fact repeated in his ontogenetic explanation, in which individual consciousness emerges from lower levels at different stages. According to Morgan, there is a stage in the individual development of an organism at which consciousness is eventually emergent, when there are sensory presentations that carry no meaning; at such a stage a behaviouristic interpretation is sufficient to catch what happens, even if we acknowledge psychical correlates. Behaviour towards "this or that thing," in fact, is the "natural progenitor under emergent evolution, of conscious reference to this or that object." However, behaviour does not initially "depend on conscious reference" (Morgan 1927: 107). One has therefore to distinguish between the primary behaviour on the level of life and the secondary, that is, "minded" behaviour which "seeks and finds again on the plane of consciousness." But Morgan specifies that the behaviourist "will not allow" such a "minded" behaviour (ibid.: 110). It is worth noting that Morgan explicitly refers to the "behaviourist" for he is decidedly criticising Watson's reductionist version of behaviourism. By referring to "minded behaviour" he, probably unknowingly, was in line with Mead's version of behaviourism, according to which it is not possible to deny the functional role of consciousness. Mead uses in fact the expression "mental behaviour" to highlight thinking processes (Mead 2015). More specifically, Mead (1936: $392 \mathrm{ff}$.) distinguished a double perspective from which to consider the notion of "behavior": the Watsonian perspective, which considered the process of the organism from an external point of view, and the Deweyan perspective, which also included in human behavior the different values associated with the notion of "consciousness." This second perspective, based on the organic circuit theory (Dewey 1896), which interpreted consciousness in functional terms as an experience of the interaction of the individual with the physical and social environment, made it possible to overcome the reductionist pattern of stimulus-response - an echo of the ancient dualism between sensation and idea - and to consider human conduct as the active product of the inhibition of actions initially related to physiological impulses. The peculiarity of human consciousness results therefore strictly from its intertwinement with a physiological system. In particular, thanks to the elaboration of a theory of perception that indicated in the manipulative capacity the bio-social element of connection between higher physiological and cognitive processes, and in the cooperative process of behavioural interaction based on primitive social instincts (Mead 2001) the condition of possibility of learning shared meanings, Mead managed to overcome the limits of psychophysical parallelism (Mead 1908; 1938). The experience of manipulation marks the border between animal and human perceptive abilities. Thanks to manipulation organism form a perceptive consciousness of the sensible stimulus, giving rise to a meaning of the object manipulated. In this framework, the mind is the evolutionary result of a transfer of the significant behavioural-based semantic from something external and physical, that is fully implemented in the field of social experience and in the individuals' inner space of a symbolic-based semantic.

31 This is a further element that allows us to assimilate Morgan's theory to Mead's explanation of the genesis of the mind and selves. ${ }^{26}$ Unknowingly in line with this perspective, in fact, Morgan argued that what is perceptually minded is "a set of signs, [...] which primarily, for purpose of behaviour, are referred to centres of physical effluence thereby signified" (Morgan 1927: 196). To "perceive" as well as to "mind" the world is to attribute to it some practical meaning, which can be an unreflective or a reflective meaning. The first has immediate utility for practical behaviour, whereas the 
second has mediate value for conduct. As Morgan argues, through its relation to meaning the presentation of the object is raised to the level of a percept which "is not a resultant but an emergent with a quality which is genuinely new." In other words, "no meaning, no percept; and no perception, no object thereof" (ibid.: 98). Accordingly, there is no separation between the sensory nucleus that is given in presentation and something else that is revived in re-presentation. They are what is minded under perception and can only be distinguished under analysis. The image is hence an image of the object, the name of which is a sign. The sign has reference to that which is signified and "shall serve as a guide to behaviour towards the thing that is signified" (ibid.: 238). To express it differently, the sign has a behavioural character. This implies that some properties of an object belong wholly to the acknowledged thing and their very existence demands a relatedness with persons and with their way of behaving accordingly.

Nevertheless, Morgan's explanation of the link between sign and behaviour is very lacking and superficial. He does not offer any answer to the question of the passage from a pre-linguistic semantics to a linguistic one, i.e. symbolic-conceptual, leaving the question unresolved and in so doing recurring in the old associationist perspective. Mead, by contrast, offers a perspective that provides a hypothesis that is still relevant today. ${ }^{27}$ In particular, he refers to gestures as communicative devices in the triadic relation between organisms, and between organisms and environment. Through gestures, seen as organic preparations for action, the cooperative acts emerge, in the sense that the individual's gestural and vocal responses arise in answer to indications of various movements performed by other individuals of the group. In other words, gestural conversation expresses a kind of "self-socialization" process of the organism. Such a process depends on the organism's bio-social mechanism of simulation of social response (Mead 1964: 100; 140): imaginative ability and the social context in which it is situated are the two components developed thanks to the evolution of gestural interactions (Mead 2015: 45-7).

\section{A Perspective Ontology of Selves}

Even if the physical world exists independently of any sensory acquaintance, it is nowise affected by individual's perception of it, and in particular by her seeing it. Morgan believed that so far as the outer world functions as a term in the cognitive relation, that is as percept, it is what it is in virtue of that relation, and as such it takes its status in internal relatedness. As a term under such relatedness its esse is percipi, but only as term, not coincidently as thing. In other words, it is what Mead would have called "the world that is there" (Mead 1938), which, however, qua minded, is founded primarily on the correlated outcome of receptor-patterns, and it is the outcome of a prolonged evolutionary process in which "vision has come to play the leading role," but it is co-related with other modes of sensory experience, especially "that of contacttreatment founded on the more primitive data of touch supplemented by manipulation" (Morgan 1927: 47).

From the ontogenetic perspective, both Morgan and Mead assumed the hypothesis of psycho-physical correlation, arguing that at each level there is one kind of relatedness which can be distinguished as correlation. Consciousness is therefore a quality of the person, as a mind-body correlation. Mind emerges within the personal system, and all 
that is minded is intrinsic to the psychical system, belonging to the bio-graphy of persons. Thus, if we consider a person as a mind-body system, there are many events that concur at all levels of reality. There are physio-chemical events, organic events, conscious events, all of which are integrated in the running of the system as a whole and their quasi-independence can only be considered via conceptual analysis. A person is at once part of the natural system (physical laws and neuro-biological states, or what Morgan called "life") which makes her locomotion possible, and part of the social system which is a part of the life system. As Mead puts it:

The point is that a body belonging to a system, and having its nature determined by its relations to members of that system, when it passes into a new systematic order will carry over into its process of readjustment in the new system something of the nature of all members of the old. So in the history of a community, the members carry over from an old order their characters as determined by social relations into the readjustments of social change. The old system is found in each member and in a revolution becomes the structure upon which the new order is established. (Mead 2002: 77)

It is interesting to note that like Mead, Morgan also contended that a person is a different term in each different relation. She becomes a new term, and in this becoming the terms "spring into existence with the relations as such in the course of evolutionary progress" (Morgan 1927: 73). The persons are in relations like the earth and the moon are in gravitational relation, and for science they are just gravitational terms within the universe of discourse. It is not a question of what they are "made of," but of the nature of their relatedness. The terms are applied to persons or things in virtue of the offices they hold in relation to other persons or things.

Like Morgan, Mead refers to the theory of relativity to analogically stress sociality as a constitutive feature of the natural and human world. He argued that the relativity of space and time with respect to the reference systems and the order in which events take place would imply a perspective ontology in which individuals organize in the present the events from their space-time point of view and reproduce their own schemes of action in the passage, acting in reality according to their perspectives. ${ }^{28}$ The order, however, is not arbitrary, i.e., subjectivistic, but it is in all respects constitutive of reality, precisely because reality itself is patient with such sentient individuals and is given according to their perspectives. In other words, although the theory of relativity conceives for each individual his own space-time world between these worlds, there is some uniformity that leads us to conceive the need to constitute a reality of events and interrelations that underlie our experience and that lead us to make these worlds coincide through the agreement of different perspectives. As Mead argues:

The conduct of the conscious organism is determined both by a physiological system from behind and also by a consciousness which reaches into the future. This can, of course, take place only in a present in which both the conditioning past and the emergent future are to be found; but, as these problems indicate, what is further called for is the recognition that in the present the location of the object in one system places it in the others as well. It is this which I have called the sociality of the present. If we examine the situation from the standpoint of relativity, we see that the very motion that is taking place within the system at rest carries with it a different spatiotemporal structure, which is responsible for an increase of mass within the system at rest. If we translate this into the other two situations, we see a biochemical process arising which we call life, but which so changes the conditions under which it goes on that there arises in nature its environment; and we see 
living forms selecting those past conditions which lead to future maintenance of life and thus introducing values and later meanings into nature. (Mead 2002: 86) ${ }^{29}$ consciousness the world is there in reference to the consciousness. The emergent process is therefore strictly related to selves and their behavioural relation to social and natural environments. According to Mead, the process that constitutes the reality of a living being is "one that extends beyond the form itself and involves for its expression the world within which this form lives. The reality of the process thus belongs to the world in its relation to the living being." (Ibid.: 66). And emergent events are related to habits and selective attitudes of individuals and their minds, that is to "the larger environment which the activity of the organism calls for but which transcends the present" (ibid.: 54). Sociality provides the aptitudes of anticipation and emergence is only given in the social act. Individual perspectives are indeed always acting perspectives, for just by acting intentionally individuals become social members, that is they enter into reality and life. Human intentionality and consciousness are thence part of a dynamic and evolutionary framework, for once the relationalorganisation of lower-level elements is presupposed, coherence between emergentist conception of reality and naturalist explanation of the emergence of consciousness can be found. As Mead argues, no one has a mind that works isolated from the process of social life in which it has arisen or emerged, and in the course of which the model of organized social behaviour has been fundamentally impressed upon it..$^{30}$ It is, in other words, the idea of a functional perspectival approach to reality, which also Morgan seems to contend:
the same entity - Morgan writes - may stand in many relations and may function as just so many different terms in different and co-existent fields of relatedness. This does not mean that an entity is other than a system of terms in intrinsic relations, for herein lies a mark of its reality. It means rather that we are to take this for granted so that we may analytically distinguish some special part that it plays in some wider field of relatedness. (Morgan 1927: 178)

From an emergent evolution perspective, among the qualities of a thing there are the expressive character of the purely spatio-temporal order (figure, size, motions), of the physico-chemical, physiological, and, psychical relatedness, qua intrinsic - "all those characters which give to a thing, an organism, or a person, its status in the evolutionary hierarchy" (ibid.: 186). But there is also the extrinsic relatedness with the persons that use them and the functions they can have.

\section{Conclusion}

As I have tried to argue in this article, there are some interconnections and many similarities between Morgan's and Mead's works. In particular, they began their 
psychological and philosophical journeys at the same area of interests and confronted the same issues related to evolutionary theory. They reached a point at the end of their journeys where they were focusing their attention on the same philosophical hypothesis, but giving thought to different solutions. According to Morgan's idea of emergent evolution, when basic physical processes achieve a certain level of complexity of an appropriate kind, genuinely novel characteristics emerge that could not be predicted from a complete knowledge of the lower-level parts and their relations. There is, moreover, a perspectival approach to reality, according to which the ontological independence of reality is epistemological dependent on the supervenient consciousness which enters into relation with it, so that the meaning relates to the way in which things enter into relation with persons. Moreover, the emergence of novelty itself should be understood as a fully natural process, so that no extra-natural force is necessary. Emergent evolution is the expression of an orderly and progressive development, ranked among the "laws of nature," though not predictable before the novelty is emerged. The laws of nature are an expression of some natural plan behind emergent evolution, a sort of "God's plan," so that once the novelty emerges, it is possible to know the hidden natural law behind it.

41 In Philosophy of the Present, Mead moves on similar paths, synthesizing his social psychology with processual philosophy and the activity which structures the reality that the organism inhabits. Emergence as an evolutionary relational process that can only be explained a posteriori was the notion he tried to elaborate through a synthesis with respect to the possible integration of his social psychology and the theory of relativity. His aim was, similar to Morgan, to avoid any psycho-physical dualism or reductionist naturalism as well as any teleological plan. In particular, the greater attention Mead devoted to the social aspect of the emergent event led him to link emergent events to the habits and selective attitudes of the selves. In turn, his theory of mind and self as emergent phenomena of the social processes better reconciled the discontinuity of the qualitatively distinct emerging events with the continuity of the evolutionary process. In particular, Mead reconciled the discontinuity of emerging events (as qualitatively distinct from the organizational structures from which they emerge), with the continuity of the evolutionary process and the old conditions of the past. ${ }^{31}$ The attention to the triadic relationship between organism, natural and social environment led Mead to interpret the psycho-physical processes from a broader perspective, according to which human evolution occurred at a social emergent level not reducible to terms of the biological characteristics of the individuals involved. However, unlike Morgan's idea of a finalistic nature, Mead proposes an anti-finalistic teleological perspective, according to which the emergent, though part of the process, is something really new and not the result of a divine plan.

Both authors, made strong and original contributions to the evolutionary epistemology of their time, work which I think, has still much to offer to the current debate on emergence and evolutionary epistemology. Mead's theory of emergence has to be considered, in my opinion, at the basis of his theory of the evolution of mind and language. Moreover, as El Hani and Pihlström (2002) have argued, Mead's antireductionist naturalism, together with that of Dewey, is so closely related to emergentist thought that they should be taken into account as some of the most creative representatives of emergentism. 


\section{BIBLIOGRAPHY}

ADLER Leonore Loeb, (1973), "Contributions of C. Lloyd Morgan to Comparative Psychology," Annals of the New York Academy of Sciences, 223 (1), 41-8.

ALEXANDER Samuel, (1920), Space, Time, and Deity, New York, The Humanities Press.

ALEXANDER Samuel, (1921), Spinoza and Time, London, George Allen \& Unwin Ltd.

ANGELL James Rowland \& Addison W. MOORE, (1896), "Studies from the Psychological Laboratory of the University of Chicago: 1. Reaction-Time: A Study in Attention and Habit," Psychological Review 3, 245-58.

ARNET Evan, (2019), "Conwy Lloyd Morgan, Methodology, and the Origins of Comparative

Psychology," Journal of the History of Biology 52, 433-61.

BALDWIN James Mark, (1896), “A New Factor in Evolution,” American Naturalist 30, 441-51, 536-53.

BEDAU Mark A. \& Paul HUMPHREYS (eds), (2008), Emergence: Contemporary Readings in Philosophy and Science, Cambridge, MA, MIT Press.

BELLA Michela, (2016), "La realtà oggettiva delle prospettive. Una lettura del realismo di Mead," in Nieddu A. (ed.), La filosofia sociale di George H. Mead. Analisi, interpretazioni, prospettive, Milano, Mimesis, 63-74.

BELLA Michela, (2019), Ontology after Philosophical Psychology, Lanham, Lexington.

BERGSON Henri, (1910), Time and Free Will, An Essay on the Immediate Data of Consciousness, London, George Allen \& Unwin Ltd.

BLITZ David, (1992), Emergent Evolution: Qualitative Novelty and the Levels of Reality, Dordrecht, Kluwer.

BOAKES Robert, (1984), From Darwin to Behaviorism: Psychology and the Minds of Animals, Cambridge, Cambridge University Press.

BRIOSCHI Maria Regina, (2013), "A Niche for Subjectivity: Emergence and Process According to S. Alexander and A. N. Whitehead,” Nóema, 4 (2), 81-103.

BURKHARDT Richard W. Jr., (1999), "Ethology, Natural History, the Life Sciences, and the Problem of Place," Journal of the History of Biology 32, 489-508.

CAHOONE Lawrence, (2019), "Mead and the Emergence of the Joint Intentional Self," European Journal of Pragmatism and American Philosophy, XI, 2, Online: [journals.openedition.org/ejpap/ 1683].

CHALMERS David, (2006), "Strong and Weak Emergence," in P. Davies \& P. Clayton (eds), The ReEmergence of Emergence: The Emergentist Hypothesis From Science to Religion, Oxford, Oxford University Press, 244-54.

CLAYTON Philip \& Paul DAVIS (eds), (2006), The Re-Emergence of Emergence. The Emergentist Hypothesis from Science to Religion, Oxford, Oxford University Press.

costall Alan, (1998), "Lloyd Morgan and the Rise and Fall of 'Animal Psychology'," Society and Animals, 6 (1), 13-29.

CUnNINGHAm Bryon, (2001), “The Remergence of 'Emergence', Philosophy of Science, 68 (3), S62-S75. 
DALTON Thomas C., (2002), Becoming John Dewey. Dilemmas of a Philosopher and Naturalist, Bloomington \& Indianapolis, Indiana University Press.

DAVENPORT Charles B., (1917), "The Personality, Heredity and Work of Charles Otis Whitman," American Naturalist 51, 5-30.

DEWEY John, (1894), “The Theory of Emotion,” in Id., The Early Works, Vol. 4, edited by J. A. Boydston, Carbondale, IL, Southern Illinois University Press, 1971, 152-69.

DEWEY John, (1895), “The Theory of Emotion,” in Id., The Early Works, Vol. 4, edited by J. A. Boydston, Carbondale, IL, Southern Illinois University Press, 1971, 169-88.

DEWEY John, (1896), “The Reflex Arc Concept in Psychology,” in Id., The Early Works, Vol. 5, edited by J. A. Boydston, Carbondale, IL, Southern Illinois University Press, 1972, 96-110.

DEWEY John, (1997), The Correspondence of John Dewey, 1871-1952 (I-IV), Electronic edition, Volume 1, 1871-1918.

DUVERNOY Russell, (2015), “'Concepts' and Continuity: Onto-Epistemology in William James," Transactions of the Charles S. Peirce Society, 51 (4), 508-30.

EL-HANI Charbel Niño, (2002), “On the Reality of Emergents," Principia: An International Journal of Epistemology, 6 (1), 51-87.

EL-HANI Charbel Niño \& Sami PIHLSTRÖM, (2002), "Emergence Theories and Pragmatic Realism," Essays in Philosophy 3 (2), article 3, Online: [commons.pacificu.edu/eip/vol3/iss2/3].

FITZPATRICK Simon \& Grant GOODRICH, (2017), "Building a Science of Animal Minds: Lloyd Morgan, Experimentation, and Morgan's Canon," Journal of the History of Biology 50, 525-69.

HODGSON Geoffrey, (2000), "The Concept of Emergence in Social Science. Its History and Importance," Emergence. Complexity and Organization Online: [journal.emergentpublications.com/ article/the-concept-of-emergence-in-social-science/].

HUEBNER Daniel R., (2014), Becoming Mead. The Social Process of Academic Knowledge, Chicago and London, The University of Chicago Press.

HUMPHREYs Paul, (2016), Emergence. A Philosophical Account, New York, Oxford University Press.

JAMES William, (1890), Principles of Psychology, New York, Henry Holt \& C.

KIM Jaegwon, (1999), “Making Sense of Emergence,” Philosophical Studies 95, 3-36.

KIM Jaegwon, (2006a), “Emergence: Core Ideas and Issues,” Synthese, 151 (3), 547-59.

KIM Jaegwon, (2006b), "Being Realistic about Emergence," in Clayton P. \& Davies P. (eds), The Reemergence of Emergence, New York, Oxford University Press, 189-202.

LAwson Tony, (2013), "Emergence and Morthogenesis: Causal Reduction and Downward Causation," in Archer M. (ed.), Social Morphogenesis, Dodrecht, Springer, 61-84.

LOTA Kenji, (2017), “Emergentism Reconsidered,” Res Cogitans, 8 (1), 30-40.

MAIENSCHEIN Jane, (1988), "Whitman at Chicago: Establishing a Chicago Style of Biology?," in Ronald Rainger, Keith R. Benson \& Jane Maienschein (eds), The American Development of Biology, Philadelphia, University of Pennsylvania Press, 185-218.

MARTIN Jack, (2005), "Perspectival Selves in Interaction with Others: Re-reading G. H. Mead's

Social Psychology," Journal for the Theory of Social Behaviour, 35 (3), 231-53.

MCNEILl David, (2005), Gesture and Thought, Chicago, Chicago University Press. 
MEAD George Herbert, (1895a), "A Theory of Emotions from the Physiological Standpoint," (Abstract of a paper read to the third annual meeting of the American Psychological Association, 1894), Psychological Review 1, 162-4.

MEAD George Herbert, (1895b), "Review of An introduction to Comparative Psychology by

C. L. Morgan," Psychological Review 2, 399-402.

MEAD George Herbert, (1908), “Concerning Animal Perception,” Psychological Review 14, 383-90.

MEAD George Herbert, (2002 [1932]), The Philosophy of the Present, Amherst, NY, Prometheus Books.

MEAD George Herbert, (2015 [1934]), Mind, Self, and Society, ed. Charles W. Morris, Chicago,

University of Chicago Press.

MEAD George Herbert, (1936), Movements of Thought in the Nineteenth Century, ed. Merritt H. Moore, Chicago, University of Chicago Press

MEAD George Herbert, (1938), The Philosophy of the Act, ed. Charles W. Morris with John M.

Brewster, Albert M. Dunham and David Miller, Chicago, University of Chicago Press.

MEAD George Herbert, (1964), Selected Writings, ed. A. J. Reck. Chicago, University of Chicago Press.

MEAD George Herbert, (1997), Letter to John \& Alice Chipman Dewey (1895.03.24), in Dewey (1997).

MORGAN Cowny Lloyd, (1891-1892), Animal Life and Intelligence, London, Edward Arnold.

MORGAN Cowny Lloyd, (1892a), “The Law of Psychogenesis," Mind, New Series, 1 (1), 72-93.

MORGAN Cowny Lloyd, (1892b), "Mental Evolution. An Old Speculation in a New Light," The Monist, $2(2), 161-77$.

MORGAN Cowny Lloyd, (1892c), “The Limits of Animal Intelligence,” Nature 46, 417.

MORGAN Cowny Lloyd, (1903 [1894a]), An Introduction to Comparative Psychology, London and New

Castle on Tyne, The Walter Scott Publishing \& Co.

MORGAN Cowny Lloyd, (1894b), “Three Aspects of Monism," The Monist, 4 (3), 321-32.

MORGAN Cowny Lloyd, (1896), Habit and Instinct, London-New York, Edward Arnold.

MORGAN Cowny Lloyd, (1912), Instinct and Experience, New York, MacMillan Company.

MORGAN Cowny Lloyd, (1913), Spencer's Philosophy of Science, Oxford, Clarendon.

MORGAN Cowny Lloyd, (1927), Emergent Evolution, London, Williams And Norgate.

MURPHY Arthur E., (2002), “Introduction," in Mead George Herbert (2002 [1932]), The Philosophy of the Present, Amherst, NY, Prometheus Books.

OKASHA Samir, (2012), "Emergence, Hierarchy and Top-Down Causation in Evolutionary Biology," Interface Focus, 2 (1), 49-54.

PARRAVICINI Andrea, (2016), "Evoluzione, emergenza del sé e socialità. Un confronto tra Mead e Darwin," in Nieddu A. (ed.), La filosofia sociale di George H. Mead. Analisi, interpretazioni, prospettive, Milano, Mimesis, 229-43.

PARRAVICINI Andrea, (2019), "Pragmatism and Emergentism in Chauncey Wright's Evolutionary Philosophy," European Journal of Pragmatism and American Philosophy, XI, 2, Online:

[journals.openedition.org/ejpap/1623].

PAULY Philip J., (1987), Controlling Life. Jacques Loeb and the Engineering Ideal in Biology, New YorkOxford, Oxford University Press. 
PAULY Philip J., (1994), "From Adventism to Biology - the Development of Whitman, Charles Otis," Perspectives in Biology and Medicine 37, 395-408.

PERTILE Chiara, (2019), "Selezione organica ed eredità sociale. Sguardo sul pensiero evoluzionistico di James Mark Baldwin,” Nóema 9, 24-39.

PETERSON Erik L., (2016), The Life Organic: The Theoretical Biology Club and the Roots of Epigenetics, Pittsburgh, University of Pittsburgh Press.

PIHLSTRÖM Sami, (2002), “The Re-Emergence of the Emergence Debate,” Principia: An International Journal of Epistemology, 6 (1), 133-82.

RICHARDS Robert J., (1977), “Lloyd Morgan's Theory of Instinct: From Darwinism to Neo-

Darwinism," Journal of the History of the Behavioral Sciences 13, 12-32.

RICHARDS Robert J., (1988), Darwin and the Emergence of Evolutionary Theories of Mind and Behavior, Chicago-London, The University of Chicago Press.

RIzZolatTI Giacomo \& Corrado sinigaglia, (2006), So quel che fai, Milano, Raffaello Cortina.

SARTENAER Olivier, (2016), “Sixteen Years Later: Making Sense of Emergence (Again)," Journal for General Philosophy of Science, 47 (1), 79-103.

SAWYER R. Keith, (2001), "Emergence in Sociology: Contemporary Philosophy of Mind and Some Implications for Sociological Theory," American Journal of Sociology, 107 (3), 551-85.

SMITH Olav Briant, (2010), “The Social Self of Whitehead's Organic Philosophy," European Journal of Pragmatism and American Philosophy, 2 (1), 50-64. Online: [journals.openedition.org/ejpap/935].

SOBER Elliott, (2005), “Comparative psychology meets evolutionary biology: Morgan's canon and cladistics parsimony," in L. Daston \& G. Mitman (eds), Thinking with Animals: New Perspectives on Anthropomorphism, New York, Columbia University Press, 85-99.

STONE Jake E., (2013), “Mead's Interpretation of Relativity Theory,” The Journal of Speculative Philosophy, 27 (2) (New Series).

THOMAS Roger K., (1998), “Lloyd Morgan's Canon,” in Greenberg G. \& Haraway M. M. (eds), Comparative Psychology: A Handbook, New York, Garland Publishing Co.

TONONI Giulio \& Christof косн, (2015), “Consciousness: Here, There and Everywhere?,"

Philosophical Transactions of Royal Society B, 370, Online: [doi.org/10.1098/rstb.2014.0167].

WHITEHEAD Alfred North, (1919), An Enquiry Concerning the Principles of Natural Knowledge, LondonNew York, Cambridge University Press.

WHITEHEAD Alfred North, (1920), The Concept of Nature, London-New York, Cambridge University Press.

WHITEHEAD Alfred North, (1925), Science and the Modern World, New York, The MacMillan Company. WHITMAN Charles O., (1899), “Animal Behavior," Biological Lectures delivered at the Marine Biological Laboratory of Wood's Holl 1898, 285-338.

wUNDT Wilhelm, (1906 [1863]), Vorlesungen über die Menschen- und Tierseele, Hamburg und Leipzig, Verlag Von Leopold Voss. 


\section{NOTES}

1. In the preface, Lloyd Morgan writes to "be glad to learn that further observations [...] on habit and instinct will probably form part of Prof. Whitman's work at an experimental station in connection with the Biological Department of Chicago University." (Morgan 1896). See Richards 1977. As evolutionary biologist, Whitman was interested in particular in the study of animal behavior, and he came to formulate the idea that instinctive behavior patterns, just like organic structures, can be used in reconstructing phylogenies (Whitman 1899). Konrad Lorenz "would later call this idea the founding concept of twentieth-century ethology, the 'Archimedean point' on which comparative behavior studies turned" (Burkhardt 1999: 497). On Whitman's contribution to the development of American Biology see among others Burckhardt 1999, Pauly 1994, Maienschein 1988, Davenport 1917.

2. As Pauly (1987: 67) argues, Whitman's entrepreneurial concern to organize biology, while antedating his arrival in Chicago, fit easily into Dewey's general framework. He was typical in arguing that "through cooperative institutions, such as the University of Chicago and the Marine Biological Laboratory, scientists would be able to communicate and coordinate their seemingly disparate individual labors, thereby creating higher intellectual syntheses than would be possible in more primitive social surroundings." He was intellectually concerned with the principles of progressive evolution and once recruited at Chicago in 1892, he appointed among other colleagues, the physiologist Jacques Loeb.

3. For a recognition see Clayton \& Davies 2006, and the introduction to this Symposia.

4. On this point see also Peterson (2016: ch. 1). Only four years before, in The Law of Psychogenesis (Morgan 1892a), Morgan published an associationist theory of consciousness and psychogenesis with some references to James's functionalism. In that article, he analysed the reflex-act, regarding consciousness as developed in the loop-line between stimulus and response, claiming that as consciousness becomes more complex through an increasing body of representative state of consciousness, "it comes to symbolise in mental terms the occurrences both on the side of stimulus and on the side of response" (Morgan 1892a: 72). Morgan also quoted James's Principles of Psychology to argue that the mechanism of control exercised by consciousness is at the basis of the ideal action, which is an "action in the line of greatest resistance" (James 1890, II: 549).

5. It has to be specify, however, that although Morgan refers to "biogenesis" and "genetic phases" of natural evolution in Instinct and Experience (Morgan 1912), the word gene is not a Morgan's word. It was Johannsen in 1909 who coined the term "gene." Even though Mendel was hypothesizing, already in 1866, the hereditary behavior of miniscule hidden factors or determinants underlying the stably inherited visible characteristics of an organism, which today we would call genes, he never used the word "gene."

6. See Sober 2005: 88; Thomas 1998. Morgan first formulated the canon in 1892 (Morgan 1892c). Though Morgan aimed to avoid errors of over-interpretation of animal behaviour (i.e. anthropomorphic explanations), he also believed, differing from the successive radicalisations of his principle carried out in behaviourism, that man could interpret the psychology of animals only in his own terms. After all, as Adler noted, it was here that Morgan "had first hand knowledge, especially through investigations of his own mental processes, which included studies of their nature and of their sequential progress" (Adler 1973: 41). On Morgan's contribution to the foundation of the modern comparative psychology see Fitzpatrick \& Goodrich 2017; Arnet 2019.

7. The notion of energy was at that time crucial for Morgan's theory of mental evolution. Though at that time British scientists and engineers - William Thomson, J. P. Joule, W. J. M. Rankine, and J. C. Maxwell - were formulating a new science of energy during the nineteenth century, it is more plausible that Morgan referred to the concept of "psychodynamics" of the German physiologist Ernst Wilhelm von Brücke who formulated in coordination with physicist Hermann 
von Helmholtz the theory on the conservation of energy. Morgan introduced the notion of energy in the article on Mental Evolution, in which he contended that consciousness is a product of brain, meaning by the term "product" the fact that it is "called into existence" by physical processes (Morgan 1892b: 163). His hypothesis, already published in his 1891 Animal Life and Intelligence (Morgan 1891-1892), was that as material structure has evolved from lower forms of matter, and organic forms of energy from lower forms of energy, so mental states evolve from lower forms of infra-consciousness, that is, from "what is of the same order of existence as consciousness, but has not yet risen to the level of consciousness" (Morgan 1892b: 172).

8. It is noteworthy that the same theory was developed in the very same year by James Mark Baldwin, under the name of "organic selection" (Baldwin 1896). See on this Pertile (2019: 28).

9. Morgan's ambiguity is even more evident in the definition of experience that he proposes. On this point see also Instinct and Experience (Morgan 1912). It would be interesting to consider the similarities between Morgan's and James' notion of experience. It is in fact most likely that Morgan's concept of "experience" derived from James's psychology. However, it is not the intention of this article to go into this aspect in greater depth. On James's ontology see Bella 2019; Duvernoy 2015.

10. See Richards (1988: 381-5).

11. In other words, neural processes and states of consciousness are radically and absolutely “ distinguishable but not separable" elements (Morgan 1892b: 169; 173).

12. As he wrote: "According to the monistic hypothesis, every mode of kinesis has its concomitant mode of metakinesis, and when the kinetic manifestations assume the form of the molecular processes in the human brain, the metakinetic manifestations assume the form of human consciousness." (Morgan 1891-1892: 467). To better understand Morgan's distinction between metakinetic and kinetic manifestations one has to take into account that Morgan's epistemological perspective before 1894 sought to promote an empiricist attitude; however, his approach was still contaminated by an old-fashioned empiricism together with a Kantian mood (ibid.: 473). So that, in perceiving an object, the mental process (that is, the perception) is considered as "the metakinetic equivalent of certain kinetic changes among the brain-molecules" (ibid.: 473).

13. George Herbert Mead to John \& Alice Chipman Dewey (1895.03.24), in Dewey 1997.

14. Loeb, Dewey and Mead were colleague for eight years at Chicago. Dewey's correspondence indicates, furthermore, that the Loebs and Meads were personally close and Huebner recently showed that Mead was directly in dialogue with Loeb's comparative physiology and psychology (see Huebner 2014: 259). During that time, Dewey and Loeb families became well acquainted. "They lived near each other, Anne Loeb and Alice Dewey had similar backgrounds and interests, and the Loeb and Dewey children were "pals." The Loebs sent their oldest son Leonard to the Deweys' laboratory school soon after it opened in 1896." In the 1890s Dewey considered Loeb in some respects as "the single most important live model [...] of the scientific inquirer" (Pauly 1987: 68). According to Dalton (2002: 70): "Loeb provided Dewey a sophisticated understanding of the intricate interrelationships between environmental influences, biological processes of growth, and learning. Loeb's studies suggested to Dewey that given appropriate stimulation during early development, each child could best employ the resources of his or her environment to fulfill that child's individual potential for learning and creativity."

15. In his letter to the Deweys he also referred to an article on the "Appearance of the Mammals" which unfortunately never appeared. This research was related to other work on emotion and the organic circuit that he was carrying out with Dewey (see Dewey 1894, 1895; Mead 1895a). In the letter Mead mentioned also the appointment of Addison W. Moore to a position as laboratory assistant of James Angell. The first result of this appointment was an experiment on "Habit and Attention," which Angell and Moore had been conducting since March 1895, the results of which they published (in the same issue of the Psychological Review where Dewey published The Reflex Arc Concept in Psychology (1896) the first statement of functionalist psychology). In the article they 
credit both Dewey and Mead for the guidance provided for the interpretation of the results presented. It would be interesting also to explore the relationships of Mead and Morgan with Baldwin, who was working on the same issues in the same years. However we cannot delve here with this topic. I intend to address this issue in a possible next contribution.

16. The question about the epistemological and methodological autonomy of experimental psychology, human and comparative, was not new. Some years before Morgan and Mead, Wundt devised the method of comparative psychology as analogous to the study of the human psyche, having indicated that the psychic life of animals was similar to that of man and therefore knowable by analogy through the observation of the phenomena of the human consciousness, which reveals itself as the immutable unit of measurement, according to which only we can measure psychic life (Wundt [1863] 1906).

17. In two articles published in the 1920s, "A Behavioristic Account of the Significant Symbol" (1922 [1964]) and "The Genesis of the Self and Social Control" (1924-1925 [1964]), and in social psychology lectures at the University of Chicago (Mead [1934] 2015), Mead repeatedly stressed the importance of using behavioural psychology to understand the psychic processes of the human being.

18. In 1913, in fact, Watson published Psychology from the Standpoint of a Behaviorist, in which he tried to extend the principles and methods of comparative psychology to the study of human beings and staunchly advocated the use of conditioning in research.

19. See Blitz 1992. For a historical overview on the notion of emergence in those author see Parravicini 2019.

20. As Peterson argues: "Even in physiologically similar organisms, psychological gaps manifested themselves. Physiological common descent Lloyd Morgan could continue to regard as an a priori truth. Behavior gaps between organisms, however, could not be dismissed so easily. But how could we explain these apparent gaps? In answering this question, Lloyd Morgan struck upon the idea of emergentism that, together with his commitment to monism, became a foundational premise of the "third way'." (Peterson 2016: 73).

21. See Murphy (2002: 14).

22. On the comparison between Mead and Whitehead see in particular Bella 2016. On Whitehead and Alexander see Brioschi 2013.

23. I believe that one issue to be explored in Mead is the distinction between the social and the relational. The use he makes of the term "social" is indeed problematic, since Mead attributes to it a wide range of meanings varying from interactions between animal organisms to institutionalised forms of human society. However, it is not possible here to expand on this aspect, which I intend to address in a later work.

24. See Whitehead (1919: 22-3). See Mead (2002: 173-4). See on this point also Smith 2010.

25. "All of the past is in the present as a conditioning nature of passage, and all the future arises out of the present as the unique events that transpire." (Mead 2002: 62).

26. See also Cahoone 2019.

27. See McNeill 2005; Rizzolatti \& Sinigaglia 2006.

28. See Stone 2013.

29. Although Mead refers to the theory of relativity, it has to be noticed that he does not unquestionably accept it. First, he notes that it is not the only explanation for the relational dimension of reality, as seen above; Newton's theory also offered a common relational structure. 30. Mead (1938: 150-1).

31. See Parravicini 2016. 


\section{ABSTRACTS}

The article aims to make a contribution to the contemporary debate on emergence by focusing on Conwy Lloyd Morgan's and George Herbert Mead's theories of emergence. Both authors, in fact, first elaborated a theory that tried to synthesize the biological, the psycho-physiological and the social dimensions of emergent processes.

Since Morgan's emergentism and Mead's processual ontology were conditioned by the reflections that the two thinkers had developed over the years and traces back their roots to the early 1890s, the article will be developed as follows. A brief description of Morgan's conception of organic and mental evolution as elaborated in the 1890s and summarised in his Lowell Lectures will be outlined. Then Mead's early writings on psychophysics and comparative psychology, pointing out a similarity between Mead and Morgan's ideas on organic and mental evolution at that time will be introduced. Finally, their theories of emergence from the 1920s, pointing out more interesting similarities and dissimilarities will be examined.

\section{AUTHOR}

\section{GUIDO BAGGIO}

Università Roma Tre

guido.baggio[at]uniroma3.it 